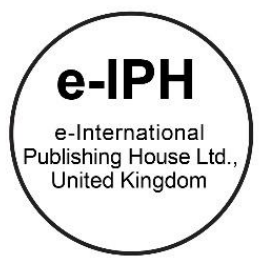

\title{
Adaptable Environment: Analysis on form and content of the Local Plan in Selangor, Malaysia
}

\author{
Suhaini Mohamed Yusoff *, Fatimah Yusoff , Ahmad Fuzi Arshad \\ Faculty of Architecture, Planning and Surveying, Universiti Teknologi MARA, 40450 Shah Alam, Malaysia
}

\begin{abstract}
Local plan is a document and written statement and supported by the proposal plan. In the content of the local plan, it includes sectoral, guideline, policy, existing land use, and projection. The objective of this paper is to evaluate whether the how adequate is the form of local plan in the application of local plan in the related local authority area and content of the local plan preparing process to meet the requirements of the (Act 172) by using the descriptive statistical analysis, and Mann-Whitney U-Test. The analysis indicated that the different form and content local plan prepared by the local authority influence the physical development in the urban area and adaptable environment as a catalyst to create a holistic development.
\end{abstract}

(C) 2016. The Authors. Published for AMER ABRA by e-International Publishing House, Ltd., UK. This is an open access article under the CC BYNC-ND license (http://creativecommons.org/licenses/by-nc-nd/4.0/).

Peer-review under responsibility of AMER (Association of Malaysian Environment-Behaviour Researchers), ABRA (Association of Behavioural Researchers on Asians) and cE-Bs (Centre for Environment-Behaviour Studies), Faculty of Architecture, Planning \& Surveying, Universiti Teknologi MARA, Malaysia.

Keywords: Form and content; local plan; local authority; environment

\section{Introduction}

This study covers two most important aspects such as form and content of the local plan in the State of Selangor. State Structure Plan, Local Plan, and Special Area Plan is also known as planning system or development plan for controlling the physical development (Ulaiman, 2009). In this paper, the researcher only focuses on the local plan aspects as a tool for controlling the development because the main purpose of the local plan is a guidance the development in term of use of land and buildings. This paper is trying to highlight the form and content of the local plan applying the adaptable environment through the physical development. According to Gary Hack (2009), he stressed that local plan is a document or written statement include the policy and strategic from the State Structure

\footnotetext{
* Corresponding author. Tel.:+0186617706

E-mail address:suhainiyusoff@gmail.com
}

2398-4287 @ 2016. The Authors. Published for AMER ABRA by e-International Publishing House, Ltd., UK. This is an open access article under the CC BY-NC-ND license (http://creativecommons.org/licenses/by-nc-nd/4.0/).

Peer-review under responsibility of AMER (Association of Malaysian Environment-Behaviour Researchers), ABRA (Association of Behavioural Researchers on Asians) and CE-Bs (Centre for Environment-Behaviour Studies), Faculty of Architecture, Planning \& Surveying, Universiti Teknologi MARA, Malaysia.

DOI: http://dx.doi.org/10.21834/e-bpj.v1i4.382 
Plan. Typically, policy and strategic refer to the development project or land use pattern for the planning activities. Meanwhile, local authorities also used the local plan for the decision making in development control and use of land in the urban area. However, the decision should be reasonable, acceptable and rationale in doing a proper planning in creating the holistic development. Furthermore, in the physical aspect, environments play the important role to maintain a balance in development accordance to conserve the green area, landscaping, and applying the green concepts by W. Arthur Lewis (2003).

From the point of view, local plan is actually based on the development plan in England (Khailani \& Perera, 2013). these instruments different with the others country and level of the development plan also contradictory regarding form and content, because it refers from the development plan in England (Khailani \& Perera, 2013). In the context of development especially land and building, local plan is one instrument or mechanism that can be used to manage the development base on the regulation Act 172. Refer to the preface of research, Malaysia itself have the local personal plan starting from 1976 until now Department of Town and Country Planning Peninsular Malaysia (2010). According to the statistic Town and Country Planning Peninsular Malaysia (2010), application of the local plan in Malaysia almost 37 years to control the development. As a mentioned, local plan in Malaysia refer to the local plan in England, and the types of the local plan are entirely different compare with Malaysia (Reade, 2005). Dimitriou, H.T., and Thompson, R. (2007) pointed out types of the local plan in England divided into three categories whereby local district plan, subject plan and local action plan. However, Salleh, D. (2007) found that in Malaysia the local authorities itself produce the special area plan, not the action area plan. Furthermore, Town and Country Planning Peninsular Malaysia (2010) identified that local plan in the State of Selangor also includes the statutory and non-statutory according to the development and use of land. As noted Richard Chapman, A. and Hun, M. (2010) there are several local plan produced by the local authorities, to provide guidance and direction for each development area. If the development is carried out unable refer to the local plan; then the urban area is unbalanced Randall G. Arendt (2009). For example, Local Government or Local Authorities (PBT) is a council that responsible for managing the development of the district. As pointed out Chandeler J.A. (2001) local authorities also established by legislation and activities are limited to the powers and duties provided in the law. However, the main duty of local authorities is to ensure the well-being and sustainability of the community by carrying out planning, implementation, and control of well planning Paul Carmichael, Arthur Midwinter (2003). Thus, this paper attempts to look into the local authorities and stakeholder in understanding the form and content of the local plan for development control in the urban area and also reflect the decision making.

\section{Literature Review}

Theoretically, local plans deal with many planning systems that influence the physical development in the urban area especially the use of land and adaptable environmental. As mentioned earlier, local plan it very importance in guiding the planning activities because it is document or report that contained the form and structure of development. As stated earlier, (Salleh 2007: p 28-29) noted that local plan provides a map or images of the proposal together with a diagram and illustrations that suitable for development and contains the written statement to support the proposal or any planning activities in the urban area. He classified that written statement describing the justification and guidelines on a proposal contained in the local plan that relates to the development and still conserves and improves the environment aspects. Adams, D. (1994) clearly point out local plans are likely to place more emphasis on the map than on the written matter, though they will usually include both. Lewis, W.A. (2003) criticism that maps should be highly descriptive such as should present as clear a picture as possible of what is proposed involved. The written part of the local plan should develop the general approach set out in the submitted plan and detail proposals. It could include sketches and photographs, including photographs of design models which may be prepared to help explain and publicise the plan Lewis, W.A. (2003). Besides that, the local plan also related to the Act and statutory instruments because under the (Act 172) local plan should be provided the legislative framework within which new plans must be drawn up. He also claimed that plan can be designed to meet the development needs and local plan also must be justified, efficient and consistent. According to (Greed, C.H. 1993) pointed out that local plan translates the policy and any proposal from the State Structure Plan. The proposal contained in the local plan is the local authority's action to develop the land in the area. He said that to show the 
details of the specific site, proposal map is made based on the ordinance survey. According to from his book, the purpose of need a zoning plan is to provide which includes the proposed development of land use. Regarding the (Manual Local Plan Edition 2013), there are two types of the local plan which Amendment Local Plan and Replacement Local Plan. These types of local plans have a different in term of the process preparation local plan. As mentioned in the manual of the local plan, amendment just includes the certain part or contain, and there are also some criteria for the amendment such as changes in proposal map and written statement. For the replacement local plan it includes the overall area in the local plan and can be done when local plan already expired, change in policy or strategic, and certain combination amendment local plan (Manual Local Plan Edition 2013).

\begin{tabular}{|l|}
\multicolumn{2}{|c|}{ Form and Content Local Plan in } \\
Adaptable Environment
\end{tabular}

\section{Methodology}

The research undertakers primary data collection using a questionnaire survey involving local authorities and consultants. The respondents chosen are based on twelve local authorities in the State of Selangor and each local authorities only two respondents are selected as samples and consultants from the listed registered members from Malaysian Institute of Planners (MIP). Regarding study area for this research it because of the significant economic nodes of the Klang Valley region with good location area rapid and dynamic growth which covers some land uses activities. The main criteria of selection respondents are those involved in the preparation local plan and expert in term of development plans and physical planning. Regarding the total samples size for this analysis is seventy-five respondents includes twenty-four from local authorities and fifty-one from consultants. For this study, questionnaire 
only used to get the data from local authorities and consultants that are involved and 75 set of questions that have been distributed. The design of questionnaire emphasizes on the three main aspects such as local plan, development control, and local planning level. Questionnaire survey was carried out to gather the data and divided into five sections, Section A: Administration power of local authority in preparing process local plan, Section B: Form of the local plan, Section C: Content of the local plan, Section D: User of the local plan and Section E: Decision making in the local plan.

However, to complete the data collection for this research, interview also as a method to get the information related to the form and content of the local plan. Expert interview opinion divided into four categories such as federal from the Town and Country Department of Peninsular Malaysia (JPBD HQ), the state which is Town and Country Planning Department State of Selangor (JPBD State), Local Authorities from the three case study area and consultants. Total sample sizes for expert interview opinion are eleven that consists of 2 respondents from JPBD $(H Q)$, two respondents JPBD State, one respondent from each local authority from case study area and four from consultants. Interview session with the expertise is just to support the information on quantitative analysis in this research. The method that used for the expert interview is judgmental sampling because it depending on their expertise and experience about the form and content of the local plan. This paper concentrates on three main aspects that related to the title of research which form, content and process of the local preparation plan. Thus, Table 1 shows the related aspects in detailed:

Table 1: Local plan aspect and indicators

\begin{tabular}{cll}
\hline Local Plan Aspects in Adaptable Environment & \multicolumn{1}{c}{ Variables } \\
\hline & Form & $\begin{array}{l}\text { Proposal and written statement in the } \\
\text { local plan }\end{array}$ \\
Development Control & Content & $\begin{array}{l}\text { Content local plan accordance to } \\
\text { manual and Act 172 }\end{array}$ \\
& Process Preparation & Process preparation local plan before \\
Implementation & Local Plan & and after the implementation \\
\hline
\end{tabular}

According to Table 1, it provided or representation of the local plan aspects with the indicators related to the research. Regarding this study, collected data gathered by using the statistically analysed which is SPSS. Before researcher goes through with this aspect of on local plan, the reliability test was conducted for each variable. The main purposed reliability test conducted just to check the consistency of related aspects in this research based on the Cronbach Alpha's value. All the variables have reliability value which is exceed .7, and the higher scores are .925. To further this analysis, researcher used Mann-Whitney $U$ Test for the non-parametrical to measure the correlation between two group which government planner and consultants for the selected variables includes form of the local plan, local plan accordance with manual, problem in process preparation local plan, problem after the implementation local plan and form and content local plan meet the current development. Meanwhile, this research also used descriptive statistical analysis for the certain aspect which definition was written statement and content local plan accordance Act 172 because this technique easy to understand and interpret (Pallant 2010).

\section{Finding}

\subsection{Form of the local plan}

The table 2 below provides the distribution of the perception of respondents regarding the type of form of the local plan. As was discussed earlier, the form of the local plan divided into two categories which are proposal map and written statement. Proposal; map in the local plan are designed to inform the public, owners, and developers. Accordingly in all cases, they will contain a map that demonstrates the land use implications of the policies and 
proposal in the plan. In this analysis, it shows that $100 \%$ majority of respondents stated that form of the local plan consists of proposal map and written statement from the total samples 75 respondents. Result formulated using the cross tabulation technic between the government planner and consultants. Respondents from government planner reported of $32 \%$ form of the local plan consist of proposal plan and written statement and followed by consultants with $68 \%$ for these variables. This is because government planner and consultants have the same opinion on types of form local plan. According to the amendment of the Act in 1995 (Act A933), local plan "shall consist of a map accompanied by a written statement showing in more detail of local authorities proposals for the development and use of land in the area of the local plan, including measures for the improvement of the physical environment. In generally, proposal map is also known as identifying the area that can be developed and protected. In between, proposal map also show areas at risk from flooding, allocate sites for particular land use and which specific policies can apply for the certain development. Researcher sees that it is different between the proposal map and written statement in this context of the local plan. In generally, the function of the local plan referred to the refining development control policies of the structure plan and translated to more detail in the local plan. However, the local plan also related to the coordinating developments in term of physical social and economic in the urban area to maintain the balancing of planning development and application development of a structure plan strategy. At this point, it must be clearly recognized that proposal map of the form of the local plan consist of a map, diagram, and some illustration to give the clear view when development to be implemented. Accordingly, maps, diagrams, and illustration had some criteria such as showing land use implications of the policies and proposal.

Table 2: Types of form of the local plan

\begin{tabular}{lccc}
\hline \multicolumn{1}{c}{ Variable } & Government Planner & $\begin{array}{c}\text { Respondents Group } \\
\text { Consultants }\end{array}$ & Total \\
\hline Proposal Plan & $32.0 \%$ & $68.0 \%$ & $100 \%$ \\
Written Statement & $32.0 \%$ & $68.0 \%$ & $100 \%$ \\
Total Samples $(\boldsymbol{n}):$ & $\mathbf{2 4}$ & $\mathbf{5 1}$ & $\mathbf{7 5}$ \\
\hline
\end{tabular}

\subsection{Definition written Statement}

Among these finding presented in Table 3, it shows that mean and standard deviation of each variable on definition written statement. There are some variables refer to the definition written statement which supported the statement, summary of condition or finding, mission, vision and strategy, specific development plan, schedule use of land and building, and describes content of proposal plan. The respondents were asked to identify on written statement, and the result shows that supported statement had the higher scores (4.61) equal to (.517) for standard deviation. The result also shows the lower scores which are specific development plan (4.37) with the standard deviation (.514). It can be concluded that specific development plan does not influence the definition on written statement.

Table 3: Definition written statement

\begin{tabular}{lccc}
\hline \multicolumn{1}{c}{ Variable } & $\begin{array}{c}\text { N } \\
\text { Statistic }\end{array}$ & $\begin{array}{c}\text { Mean } \\
\text { Statistic }\end{array}$ & $\begin{array}{c}\text { Std. } \\
\text { Deviation } \\
\text { Statistic }\end{array}$ \\
\hline $\begin{array}{l}\text { Supported statement } \\
\text { Summary of existing condition }\end{array}$ & 75 & 4.61 & .517 \\
or finding & 75 & 4.49 & .529 \\
$\begin{array}{l}\text { Mission, vision and strategic } \\
\text { Specific development plan }\end{array}$ & 75 & 4.51 & .529 \\
$\begin{array}{l}\text { Schedule use of land and } \\
\text { building }\end{array}$ & 75 & 4.37 & .514 \\
\hline
\end{tabular}




\begin{tabular}{llll}
\hline $\begin{array}{l}\text { Describe content of proposal } \\
\text { plan }\end{array}$ & 75 & 4.51 & .503 \\
\hline
\end{tabular}

Table 4: Summary frequency data on definition written statement

\begin{tabular}{lcccccc}
\hline \multicolumn{1}{c}{ Variables } & $\begin{array}{c}\text { Strongly } \\
\text { Disagree }\end{array}$ & Disagree & Tend to agree & Agree & $\begin{array}{c}\text { Strongly } \\
\text { Agree }\end{array}$ & Total \\
\hline $\begin{array}{l}\text { Supported statement } \\
\begin{array}{l}\text { Summary of existing } \\
\text { conditions and finding }\end{array}\end{array}$ & - & - & $1.3 \%$ & $36 \%$ & $62.7 \%$ & $100 \%$ \\
$\begin{array}{l}\text { Describe mission, vision and } \\
\text { strategic }\end{array}$ & - & - & $1.3 \%$ & $48 \%$ & $50.7 \%$ & $100 \%$ \\
$\begin{array}{l}\text { Specific development } \\
\text { guideline }\end{array}$ & - & - & $1.3 \%$ & $46.7 \%$ & $52 \%$ & $100 \%$ \\
$\begin{array}{l}\text { Schedules use of land and } \\
\text { building }\end{array}$ & - & - & $1.3 \%$ & $60 \%$ & $38.7 \%$ & $100 \%$ \\
$\begin{array}{l}\text { Describe content of proposal } \\
\text { plan }\end{array}$ & - & - & - & $53.3 \%$ & $46.7 \%$ & $100 \%$ \\
\hline
\end{tabular}

According to the results in Table 3 above, the higher percentage for the first variable is supported the statement with the $62.7 \%$ strongly, while $36 \%$ agree and $1.3 \%$ tends to agree. This results shown that most of the respondents choose the strongly agree because supported statement described the policies and explained on the development land use. Thus, in this analysis, it shows that $50.7 \%$ strongly agree, $48 \%$ agree and $1.3 \%$ tend to agree with the second variable on a summary of existing conditions and finding. The supported statement has a wide scope to describe on condition and finding in the local plan. Besides that, the existing condition also discussed on population projection and population density to the suite with the current development need and for the future. Summary of condition and finding also outlined the early issues and also the potential in the area and to facilitate the preparation of physical activity land use. As the table 3 , above was interpreted definition written statement and there is results for the third variable recorded that $52 \%$ strongly agree, while $46.7 \%$ agree and $1.3 \%$ tend to agree with written statement describe the mission, vision and strategic of development in the local plan. Mission and vision designed based on the State Structure Plan in Selangor to meet the need of development in the area. The vision and strategy are very important to ensure the establishment of a sustainable environment, dynamic domestic economy and a better quality of life. According to the fourth variable, results shows that $60 \%$ agree, while $38.7 \%$ strongly agree and the rest is $1.3 \%$ tend to agree. In this study, the guideline is a part of written statement in the local plan because it acts as an instrument to control the development. This is illustrated in Table 4 above; the table shows that the higher percentage for the fifth variable reported of $53.3 \%$ agree to written statement also refer to schedules use of land and building while $46.7 \%$ strongly agree for this variable. It can be seen that written statement also translated the description into the schedules, so it's easy for users to refer local plan. Hence, the last results for this subtopic found that $50.7 \%$ strongly agree and $49.3 \%$ agree to the written statement also described the content of proposal plan. As has been mentioned, proposal plan related to the zoning plan, subject plan, detail plan and intensity plan. For the definition written statement, it can conclude that both of stakeholders mostly strongly agree and agree with these statements. A written statement more on supported statement for the local plan.

\subsection{Content local plan accordance with manual produced by the state authority}

Based on Table 5 above, result found that, $(z=-4.336$ with $p=.000<.05)$. The mean rank score reported of government planner (52.50) had the higher rather than consultants (31.18). For this variable, it can be concluded that there is statistical significant in the sector distribution between the respondents group. Moreover, the analysis 
shows second variable for content, local plan accordance with the manual $(z=-1.328$ with $p=.184>.05)$, while mean rank score suggests that government planner (42.58) it just slightly more than consultants (35.84) to represent the higher overall ranking. According to the result, there is no statistical significant in the variable between the two of respondents group. From the result Mann-Whitney $U$ Test obtained for the third variable, it was found that $(z=$ 1.686 with $p=.092>.05)$ followed by the mean rank score for consultants (40.67) had the higher score compare to government planner (32.33).

Table 5: Summary statistic of Mann Whitney U Test on content local plan accordance manual

\begin{tabular}{|c|c|c|c|c|c|}
\hline Variables & Respondents Group & $\mathrm{N}$ & Mean Rank & z-value & $p$-value \\
\hline \multirow{3}{*}{$\begin{array}{l}\text { Content accordance manual local } \\
\text { plan: sector distribution }\end{array}$} & Government Planner & 24 & 52.50 & \multirow[t]{3}{*}{-4.336} & \multirow[t]{3}{*}{.000} \\
\hline & Consultants & 51 & 31.18 & & \\
\hline & Total & 75 & & & \\
\hline \multirow{3}{*}{$\begin{array}{l}\text { Content accordance manual local } \\
\text { plan: existing planning } \\
\text { development }\end{array}$} & Government Planner & 24 & 42.58 & \multirow[t]{3}{*}{-1.328} & \multirow[t]{3}{*}{. 184} \\
\hline & Consultants & 51 & 35.84 & & \\
\hline & Total & 75 & & & \\
\hline \multirow{3}{*}{$\begin{array}{l}\text { Content accordance manual local } \\
\text { plan: policy and strategic }\end{array}$} & Government Planner & 24 & 32.33 & \multirow[t]{3}{*}{-1.686} & \multirow[t]{3}{*}{.092} \\
\hline & Consultants & 51 & 40.67 & & \\
\hline & Total & 75 & & & \\
\hline \multirow{3}{*}{$\begin{array}{l}\text { Content accordance manual local } \\
\text { plan: guideline }\end{array}$} & Government Planner & 24 & 23.25 & \multirow[t]{3}{*}{-4.676} & \multirow[t]{3}{*}{.000} \\
\hline & Consultants & 51 & 44.94 & & \\
\hline & Total & 75 & & & \\
\hline \multirow{3}{*}{$\begin{array}{l}\text { Content accordance manual local } \\
\text { plan: projection }\end{array}$} & Government Planner & 24 & 61.67 & \multirow{3}{*}{-7.644} & \multirow[t]{3}{*}{.000} \\
\hline & Consultants & 51 & 26.86 & & \\
\hline & Total & 75 & & & \\
\hline
\end{tabular}

This clearly indicated that there is no statistical significant in the policy and strategic in the content of the local plan between the respondents group. Regarding the fourth variable, the result shows that $(z=-4.676$ with $p=.000<.05)$. Even though the mean rank value for consultants reported of (44.94) is higher than government planner (23.25) and the result shows that there is statistically significant in the guideline between two respondents group. For the last variable is on projection as a content of the local plan reported that $(z=-7.644$ with $p=.000<.05$ ). Specifically, the analysis recorded mean rank score for government planner (61.67) had the higher value compare to consultants (26.86). The result shows that there is statistical significant in the projection between the respondents group. In conclusion, only three variables influence the local content plan based on the manual which sector distribution, guideline, and projection. These three variables achieved the statistical significance value $(p=<.05)$

\subsection{Content Local plan Accordance to Town and Country Planning Act 172 (1976)}

Local plan in the State of Selangor refer the Act 172, and it is different between states in Peninsular Malaysian for example Sabah used Town and Country Planning Act (CAP 141). Town and Country Planning Act 172 is the mechanism to create a better form of the planning system in Malaysian, which to produce a good development with fulfilling the human need in line with developed countries in the world. According to the questionnaire survey, the higher percentage is (54.7\%) said the content of the local plan didn't follow Act 172 while (45.3\%) said 'yes' for local plan follow the Town and Country Planning Act 172. Now days, development more prefer to supply and demand physical planning, and it depends on the current situation. The pattern of current development focused on the problems in that area and mostly local authorities are looking for various alternatives to address the issues and problems. This is happened because Act 172 doesn't comprehensive, the subsection is not reviewed and unclear in term of plot ratio, building height, distance or radius of development. That why certain local authorities that responsible to prepare the local plan didn't follow the Act 172. Meanwhile, questionnaire survey also looks at the content of the local plan based on Act 172 (1976) whether it is still reliable or not for the future development. 
Table 6: Content Local plan Accordance to Town and Country Planning Act 172 (1976)

\begin{tabular}{lcccc}
\hline \multicolumn{1}{c}{ Variables } & Frequency & Percent & Valid Percent & $\begin{array}{c}\text { Cumulative } \\
\text { Percent }\end{array}$ \\
\hline Yes & 34 & $45.3 \%$ & $45.3 \%$ & $45.3 \%$ \\
No & 41 & $54.7 \%$ & $54.7 \%$ & $100 \%$ \\
Total & 75 & $100 \%$ & $100 \%$ & \\
\hline
\end{tabular}

To further this research table 7 below shows the result according to the descriptive statistically for frequencies. There are some variable to support the content of the local plan based on Act 172. Through level of agreement, the majority of respondents reported of $(89.3 \%)$ strongly agree and (10.7\%) agree on developing land and use of land as a part of the local content plan. From the frequency obtained for the other variables it was found that $(72 \%)$ strongly agree and (28\%) agree that content, local plan protection and improvement environment in term of physical. In this context, protection and improvement environment very importance, because development will not affect the permanent forest area and prevent water pollution. According to the questionnaire survey, the content of the local plan also includes conserving of nature topography reported of $(82.7 \%)$ strongly agree while $(17.3 \%)$ agree with the content of the local plan. Next is improve the landscape reported of $(58.7 \%)$ strongly agree and $(41.3 \%)$ agree. Thus, provide the open space reported of $(61.3 \%)$ strongly agree and $(38.7 \%)$ agree. This is because the provision open spaces in residential areas, industrial or town center is important. Besides, open space can prevent the area from soil erosion, floods, and others. Furthermore, (57.3\%) strongly agree and (42.7\%) agree on preservation and enhancement character and building façade. It is because; this area had sentimental value and it also reflects the identity of the area. According to the result, traffic handlings reported of $(56 \%)$ respondents strongly agree while $(44 \%)$ agree with this content based on Act 172. The next variable is improved telecommunication system reported of $(62.7 \%)$ strongly agree and (37.3\%) agree. Improvement telecommunication system can be implemented through the use of fiber optic-based system compared to copper, which is used now a high capacity to transmit data.

Table 7: Level of agreement on content local plan accordance to Town and Regional Planning Act 172

\begin{tabular}{lcccccc}
\hline \multicolumn{1}{c}{ Level of Agreement: Content Local plan Accordance to Town and Country Planning Act 172 } \\
\hline \multicolumn{1}{c}{ Variables } & $\begin{array}{c}\text { Strongly } \\
\text { Disagree }\end{array}$ & Disagree & $\begin{array}{c}\text { Tend to } \\
\text { Agree }\end{array}$ & Agree & Strongly Agree & Total \\
\hline $\begin{array}{l}\text { Develop land and use of land } \\
\text { Protection and improvement }\end{array}$ & - & - & - & $10.7 \%$ & $89.3 \%$ & $100 \%$ \\
$\begin{array}{l}\text { environment in term of physical } \\
\text { Conserve of nature topography }\end{array}$ & - & - & - & $28 \%$ & $72 \%$ & $100 \%$ \\
$\begin{array}{l}\text { Improve the landscape } \\
\text { Provide the open space }\end{array}$ & - & - & - & $17.3 \%$ & $82.7 \%$ & $100 \%$ \\
$\begin{array}{l}\text { Preservation and enhancement } \\
\text { character and building facade }\end{array}$ & - & - & - & $41.3 \%$ & $58.7 \%$ & $100 \%$ \\
$\begin{array}{l}\text { Traffic handling } \\
\text { Improve telecommunication system }\end{array}$ & - & - & - & $38.7 \%$ & $61.3 \%$ & $100 \%$ \\
\hline
\end{tabular}

\subsection{Problem in process preparation local plan}

According to the table 8, collected data from Mann-Whitney $U$ Test result shows that there no statistical significant in the difficult to get information between the government planner and consultants $(z=-.313, p=.754>.05)$. The mean rank score for consultants (38.41) reported the higher score compare to government planner (37.13). Furthermore, Table 8 shows that the result of the Mann-Whitney $U$ test applied to the existing problem while local preparation plan on the cost and result shows that there is statistically significant in the variable between the respondents group at the level of $p<.05(z=-3.927, p=.000<.05)$. From this analysis, the mean rank score for consultants recorded of (43.89) had the higher score with the government planner (25.48) reporting the lowest score. For the next variable, the result shows that there is no statistically significantly different in the co-operation between technical department with the respondents group $(z=-1.201, p=.230>.05)$. The mean rank average of the consultants was $(39.65)$, while 
government planner had a score rank average of (34.50). According to mean rank, it shows that consultants are the higher score rather than government planner.

Table 8: Summary Mann Whitney U Test on problem in process preparation local plan

\begin{tabular}{|c|c|c|c|c|c|}
\hline Variables & Respondents Group & $\mathbf{N}$ & Mean Rank & $z$-value & $p$-value \\
\hline & Government Planner & 24 & 37.13 & -.313 & .754 \\
\hline \multirow[t]{3}{*}{ Difficult } & Consultants & 51 & 38.41 & & \\
\hline & Total & 75 & & & \\
\hline & Government Planner & 24 & 25.48 & -3.927 & .000 \\
\hline \multirow[t]{2}{*}{ Cost } & Consultants & 51 & 43.89 & & \\
\hline & Total & 75 & & & \\
\hline \multirow{4}{*}{$\begin{array}{l}\text { Co-operation between } \\
\text { technical department }\end{array}$} & Government Planner & 24 & 34.50 & -1.201 & .230 \\
\hline & Consultants & 51 & 39.65 & & \\
\hline & Total & 75 & & & \\
\hline & Government Planner & 24 & 38.44 & -.181 & .856 \\
\hline \multirow[t]{2}{*}{ Consultants } & $\begin{array}{l}\text { Consultants } \\
\text { Total }\end{array}$ & $\begin{array}{l}51 \\
75\end{array}$ & 37.79 & & \\
\hline & Government Planner & 24 & 40.44 & -1.081 & .280 \\
\hline Manual unclear & $\begin{array}{l}\text { Consultants } \\
\text { Total }\end{array}$ & $\begin{array}{l}51 \\
75\end{array}$ & 36.85 & & \\
\hline \multirow[t]{2}{*}{$\begin{array}{l}\text { Amendment policy and } \\
\text { strategic }\end{array}$} & $\begin{array}{l}\text { Government Planner } \\
\text { Consultants } \\
\text { Total }\end{array}$ & $\begin{array}{l}24 \\
51 \\
75\end{array}$ & $\begin{array}{l}33.42 \\
40.16\end{array}$ & -1.616 & 106 \\
\hline & Government Planner & 24 & 26.67 & -3.533 & .000 \\
\hline Provision on Act 172 & $\begin{array}{l}\text { Consultants } \\
\text { Total }\end{array}$ & $\begin{array}{l}51 \\
75\end{array}$ & 43.33 & & \\
\hline $\begin{array}{l}\text { Takes time in process } \\
\text { of preparation local plan }\end{array}$ & $\begin{array}{l}\text { Government Planner } \\
\text { Consultants } \\
\text { Total }\end{array}$ & $\begin{array}{l}24 \\
51 \\
75\end{array}$ & $\begin{array}{l}26.19 \\
43.56\end{array}$ & -4.440 & .000 \\
\hline
\end{tabular}

Refer to the table above eight this result indicates that there is no statistically significantly different in the consultants between the respondents group $(z=-.181, p=.856>.05)$. The mean rank score it was found to be (38.44) for government planner, whereas consultants (37.79). Through this score, government planner had a higher value rather than consultants. As will be revealed in the finding, Table 8 shows that there is no statistically significantly different in the manual unclear between the respondents group $(z=-1.081, p=.280>.05)$. The mean rank for this respondents group shows that government planner (40.44) slightly more than consultants (36.85). As a result, there was no statistically significantly different in the amendment policy and strategic between the respondents group $(z=-1.616, p=.106>05)$. However, the result for mean rank score shows that consultants are the higher score compare to government planner (33.42). As shown by the result in table 1.6 there is statistically significantly different in the provision of Act 172 between the respondents group $(z=-3.533, p=.000<.05)$. This indicated that mean rank score for consultants (43.33) it just slightly more than government planner (26.67). The analysis had shown there is statistically significantly different from the takes time in the process of local preparation plan between the respondents group. Result for mean rank score illustrated those consultants is higher compare to government planner (26.19).

\subsection{Problem after the implementation local plan}

The following result shows that there is statistically significantly different in the local plan very thick between the respondents group $(z=-3.233, p=.001<.05)$. The mean rank of the problem after the local implementation plan shows that consultants (42.89) had a higher score compare to government planner (27.60). Result for produced more volume also recorded that there is statistically significant between respondent group $(z=-3.146, p=$ $.002<.05)$. However, the result for mean rank reported that consultants (42.75) it just slightly higher than government planner (27.90). Furthermore, Mann-Whitney test also shows the result there is no statistically significantly different in the local plan doesn't contain detailed development sector according to the respondent group $(z=-1.539, p=$ 
$.124>$.05). The mean rank indicated that consultants (40.24) higher than government planner (33.25). Next variable reported that there is statistically significant in the implementation doesn't follow the exact report between the respondent group $(z=-2.150, p=.032<.05)$. Meanwhile, value for mean ranks shows that consultants (41.29) higher compare to government planner (31.00). Thus, there is statistically significant in the sources or data are not valid according to the respondents group $(z=-3.570, p=.000<.05)$ and result for mean ranks shows that consultants (43.52) it just slightly more than government planner (26.27). Based on the last variable, it shows that there is statistically significant in the user-friendly between the respondents group $(z=-4.376, p=.000<.05)$. Even though the mean rank value for consultants (44.74) is higher than government planner (23.69). It can be postulated that five variables influence the problem after the local implementation plan.

\begin{tabular}{|c|c|c|c|c|c|}
\hline Variables & Respondents Group & $\mathbf{N}$ & Mean Rank & z-value & p-value \\
\hline \multirow{3}{*}{$\begin{array}{l}\text { Problem after implementation: } \\
\text { local plan very thick }\end{array}$} & Government Planner & 24 & 27.60 & \multirow[t]{3}{*}{-3.233} & \multirow[t]{3}{*}{.001} \\
\hline & Consultants & 51 & 42.89 & & \\
\hline & Total & 75 & & & \\
\hline \multirow{3}{*}{$\begin{array}{l}\text { Problem after implementation: } \\
\text { produced more volume }\end{array}$} & Government Planner & 24 & 27.90 & \multirow[t]{3}{*}{-3.146} & \multirow[t]{3}{*}{.002} \\
\hline & Consultants & 51 & 42.75 & & \\
\hline & Total & 75 & & & \\
\hline \multirow{3}{*}{$\begin{array}{l}\text { Problem after implementation: } \\
\text { doesn't contained detailed } \\
\text { development or sector }\end{array}$} & Government Planner & 24 & 33.25 & \multirow[t]{3}{*}{-1.539} & \multirow[t]{3}{*}{.124} \\
\hline & Consultants & 51 & 40.24 & & \\
\hline & Total & 75 & & & \\
\hline \multirow{3}{*}{$\begin{array}{l}\text { Problem after implementation: } \\
\text { implementation doesn't follow the } \\
\text { exactly report }\end{array}$} & Government Planner & 24 & 31.00 & \multirow[t]{3}{*}{-2.150} & \multirow[t]{3}{*}{.032} \\
\hline & Consultants & 51 & 41.29 & & \\
\hline & Total & 75 & & & \\
\hline \multirow{3}{*}{$\begin{array}{l}\text { Problem after implementation: } \\
\text { sources or data not valid }\end{array}$} & Government Planner & 24 & 26.27 & \multirow[t]{3}{*}{-3.570} & \multirow[t]{3}{*}{.000} \\
\hline & Consultants & 51 & 43.52 & & \\
\hline & Total & 75 & & & \\
\hline \multirow{3}{*}{$\begin{array}{l}\text { Problem after implementation: } \\
\text { not user friendly }\end{array}$} & Government Planner & 24 & 23.69 & \multirow[t]{3}{*}{-4.376} & \multirow[t]{3}{*}{.000} \\
\hline & Consultants & 51 & 44.74 & & \\
\hline & Total & 75 & & & \\
\hline
\end{tabular}

\subsection{Form and content meet the current development}

The output provided from Mann-Whitney $U$ Test shows that there is statistically significantly different in the form and content local plan assist the local authority between the two respondents group $(z=-6.287, p=.000<.05)$. MannWhitney also shows the result of mean rank for government planner (59.67) higher than consultants (27.80). Similarly, for the next variable the test shows that it is statistically significantly different in the development control between the respondents group $(z=-7.351, p=.000<.05)$. The mean rank score for government planner (63.50) is higher than consultants (26.00). Thus, the table below nine shows the result of this analysis reported that there is statistically significantly different in the strategic development pattern and systematic according to respondents group $(z=-6.350, p=.000<.05)$. For these data, it shows the mean rank score for government planner (63.50) had the higher value compare to consultants (28.09). This result also represents the variable on future development, and it found that it is statistically significantly different in the variable between the respondents group $(z=-5.967, p=$ $.000<.05)$. The finding indicated that mean rank score for government planner (57.54) it just slightly more than consultants (28.80).

Table 9: Summary Mann Whitney U Test on problem in form and content meet the current development

\begin{tabular}{|c|c|c|c|c|c|}
\hline Variables & Respondents Group & $\mathrm{N}$ & Mean Rank & z-value & $p$-value \\
\hline $\begin{array}{l}\text { Existing form and content local } \\
\text { plan: form and content assist the } \\
\text { local authority }\end{array}$ & $\begin{array}{l}\text { Government Planner } \\
\text { Consultants } \\
\text { Total }\end{array}$ & $\begin{array}{l}24 \\
51 \\
75\end{array}$ & $\begin{array}{l}59.67 \\
27.80\end{array}$ & -6.287 & .000 \\
\hline $\begin{array}{l}\text { Existing form and content local } \\
\text { plan: development control }\end{array}$ & $\begin{array}{l}\text { Government Planner } \\
\text { Consultants } \\
\text { Total }\end{array}$ & $\begin{array}{l}24 \\
51 \\
75\end{array}$ & $\begin{array}{l}63.50 \\
26.00\end{array}$ & -7.351 & .000 \\
\hline $\begin{array}{l}\text { Existing form and content local } \\
\text { plan: strategic development pattern } \\
\text { and systematic }\end{array}$ & $\begin{array}{l}\text { Government Planner } \\
\text { Consultants } \\
\text { Total }\end{array}$ & $\begin{array}{l}24 \\
51 \\
75\end{array}$ & $\begin{array}{l}59.06 \\
28.09\end{array}$ & -6.350 & .000 \\
\hline
\end{tabular}




\begin{tabular}{|c|c|c|c|c|c|}
\hline $\begin{array}{l}\text { Existing form and content local } \\
\text { plan: future development }\end{array}$ & $\begin{array}{l}\text { Government Planner } \\
\text { Consultants } \\
\text { Total }\end{array}$ & $\begin{array}{l}24 \\
51 \\
75\end{array}$ & $\begin{array}{l}57.54 \\
28.80\end{array}$ & -5.967 & .000 \\
\hline
\end{tabular}

\section{Discussion and Analysis}

From this analysis, it can be revealed that form and content of the local plan can be viewed in many aspect or perspective as an instrument in the development plan that assists the development control in the urban area through the adaptable environment to create a better of planning activities. According to the result through the two viewpoints of two stakeholders group which government planner and consultants. As shown by the result in Table 2, both of government planner and consultants agreed that form of the local plan consists of proposal plan and written statement. It is because proposal plan referred to the future development and shown in the plan by zoning area and written statement assists the proposal plan in making a good development. As revealed in the finding, there are some definitions on written statement and result shows that most of the respondents strongly agree and agree on the variables. Respondents felt that written statement had multiple definitions or description to represent the written statement. The study also took note on the content local plan accordance with manually produced by the state authority. From the result, only three variables influence the local content plan based on the manual which sector distribution, guideline, and projection. These three variables achieved the statistically significance value $(p=<.05)$. Based on the finding for the level of agreement on content, local plan accordance to Town and Regional Planning Act 172, it proves that both of stakeholders strongly agree on the content accordance to the Act 172. It is because; Act 172 still can be used and valid for the physical planning in line with the policy and strategy of development. Thus, result from the Mann-Whitney $u$ test indicated that consultants had a higher score of mean rank for the problem in process preparation local plan compare to the government planner. Through the $p$-value, it found that there are three variables have a statistically significant and influence the problem which cost, provision of Act 172 and takes time of process preparation local plan. For the problem after the local implementation plan, there are two variables have a statistically significant such as sources, or data are not valid and not user-friendly. As mentioned, local plan it very importance tool in to control the development, and local plan supposed to be concise, accessible and focused on the critical issues and taking care of development need in the urban area especially environment aspect. According to the form and content meet the current development, all the variables had a statistically significant and influence the form and content. The local content plan should be addressed the current issues and depend on the area.

\section{Conclusion and Recommendations}

Based on the results and analysis that have been discussed, it can be concluded that form and content local plan should be reviewed in term of process preparation before the implementation for the physical development. It is to create an effectiveness local plan, consistent, and flexible for the future especially in planning activities. The local plan should be presented to everyone, and the local authorities are responsible to provide a good manual process preparation local plan to standardize the all local plan in the country. Thus, recommendation more on role and functions local plan, process preparation local plan and decision making taking care of public interest and conserve or protecting the environment in term of enhancing the historic environment, natural, built and minimize the destruction of green areas.

\section{Acknowledgements}

Researchers would like to special thanks to Ministry of Education Malaysia for the sponsorship and three local authorities in State of Selangor which are Shah Alam City Council, Kajang Municipal Council and Kuala Langat District Council for their co-operation and support in this study. 


\section{References}

Adams, D. (1994). Urban Planning and the Development Process. Routledge is an imprint of the Taylor \& Francis Group.

Dimitriou, H.T. \& Thompson, R. (2007). A review of Principles and practices: Strategic Planning for Regional Development in the UK. Routledge Taylor and Francis Group.

Greed, C.H. (1993). Introducing Town Planning First Edition. Publish: Longman Group UK Limited.

Khailani, D. K., \& Perera, R. (2013). Mainstreaming disaster resilience attributes in local development plans for the adaptation to climate change induced flooding: A study based on the local plan of Shah Alam City, Malaysia. Land Use Policy, 30(1), 615-627. doi:10.1016/j.landusepol.2012.05.003.

Legal Research Board (2010).Town and Country Planning Act 1976 (Act 172), Malaysia : International Law Book Services.

Lewis, W.A. (2003). Development Planning, Volume 5 of Development Planning. Publisher Lewis bookstore.ellibs.com/book/0-203-00929-0.

Mahmud, Z. (2009). Handbook of Research Methodology. A simplified Version. Publisher: University Publication Centre (UPENA), UiTM.

Manual Garis Panduan dan Piawaian Perancangan Negeri Selangor Edisi Kedua/cetakan kedua (2010). Available at: http://www.jpbdselangor.gov.my/Laporan/Garis_panduan/pdf. Accessed: 11 November 2012.

Norton, R. K. (2008). Using content analysis to evaluate local master plans and zoning codes. Land Use Policy, 25(3), $432-454$. doi:10.1016/j.landusepol.2007.10.006

Pallant, J. (2010). SPSS Survival Manual (4th edition). Published: Allen \& Unwin Book Publishers Australia.

Ratcliffe, J. (1981). An Introduction to Town and Country Planning. Head of Department of Estate Management, Polytechnic of the South Bank, London. Published: Hutchinson \& Co. Ltd an Imprint of the Hutchinson Publishing Group 62-65 Chandos Place, London WC2N 4 NW

Randall G. Arendt (2009). Growing Greener Putting Conservation into Local Plans and Ordinances.Publisher : ISLAND PRESS is a trademarks of The Centre for Resources Economics.

Reade, C. C. (2005). International conference of the asian planning schools association 11-14, (September), 1-18.

Salleh, D. (2007). "Urbanisasi Perancangan dan Kawalan”. "Universiti Utara Malaysia ISBN 983-3282-12-X”.

Ulaiman, S. U. S. (n.d.). Decision Support System for Urban Sustainability Planning in Malaysia, 10(1), 101-118.

Urban Design in the Planning System (2000). Towards Better Practice. Available at http://webarchive.nationalarchives.gov.uk. Accessed: 29 November 2013

W. Lawrence Neuman (2003). Social Research Methods. Qualitative and Quantitative Approaches. Fifth Editions. Publisher: Library of Congress Cataloging in Publication Data

Zainol, H. (2000). "Pendahuluan Kepada Perancangan Fizikal". "Biroteks, UiTM Shah Alam Malaysia". 